\title{
PERBANDINGAN MODEL PROBLEM BASED LEARNING (PBL) DAN MODEL PEMBELAJARAN KONVENSIONAL TERHADAP HASIL BELAJAR IPS TERPADU SISWA SMP NEGERI 6 WELAK
}

\author{
Maria Melita R. Jemalu \\ e-mail: Melitamaria1509@gmail.com \\ Rusno \\ e-mail: rusno@unikama.ac.id \\ Udik Yudiono \\ e-mail: $\underline{\text { uyudiono@unikama.ac.id }}$
}

(Program Studi Pendidikan Ekonomi, Fakultas Ekonomika dan Bisnis, Universitas PGRI Kanjuruhan, Malang)

\begin{abstract}
ABSTRAK: Penelitian ini bertujuan untuk mengetahui hasil analisis tentang (1) nilai Hasil Belajar IPS Terpadu siswa yang diajar menggunakan model Problem Based Learning (PBL) dengan model pembelajaran konvensional. (2) nilai hasil belajar IPS Terpadu siswa yang diajar menggunakan model pembelajaran konvensional, (3) perbandingan nilai hasil belajar siswa IPS Terpadu siswa yang diajar menggunakan model Problem Based Learning (PBL) dengan nilai hasil belajar IPS Terpadu siswa yang diajar menggunakan model pembelajaran konvensional. Metode penelitian ini adalah kuantitatif dengan rancangan quasi eksperiment design. Populasi penelitian ini adalah siswa kelas VIII A dan VIII B SMP Negeri 6 Welak 2020/2021, yang totalnya berjumlah 50 siswa (kelas VIII A dan kelas VIII B masing-masing terdiri dari 25 siswa). Sampling menggunakan total sampling, sehingga semua anggota populasi ditetapkan menjadi sampel, dimana kelas VIII A ditetapkan menjadi kelas eksperimen dan kelas VIII B ditetapkan menjadi kelas kontrol. Pengumpulan data penelitian ini menggunakan teknik tes. Teknik analisis data meliputi uji normalitas, uji homogenitas, dan uji independent sample T test. Hasil penelitian ini menyimpulkan : (1) nilai hasil belajar IPS Terpadu siswa kelas VIII SMP Negeri 6 Welak yang diajar dengan menggunakan model Problem Based Learning (PBL) termasuk kategori "sangat baik", (2) nilai hasil belajar IPS Terpadu yang diajar menggunakan model konvensional termasuk kategori "baik", (3) nilai hasil belajar IPS Terpadu siswa kelas VIII SMP Negeri 6 Welak yang diajar menggunakan model Problem Based Learning (PBL) berbeda signifikan dengan nilai hasil belajar IPS Terpadu siswa yang diajar dengan menggunakan model pembelajaran konvensional.
\end{abstract}

Kata kunci - Hasil Belajar, Model PBL, Model Konvensional, IPS Terpadu

ABSTRACT: This study focuses on discussing the results of the analysis of (1) the value of integrated social studies learning outcomes of students who are taught using the Problem based learning (PBL) model, (2) the value of integrated social studies learning outcomes of students who are taught using conventional learning models, (3) comparison of the results of Integrated Social Studies learning students who are taught using the Problem based learning (PBL) model with the value of Integrated Social Studies learning outcomes students who are taught using conventional learning models. This 
research method is quantitative with a quasi-experimental design. The population of this study was students of class VIII A and VIII B of SMP Negeri 6 Welak 2020/2021, with a total of 50 students (classes VIII $A$ and VIII B each consisted of 25 students). Sampling uses total sampling, so that all members of the population are assigned to be the sample, where class VIII $A$ is assigned to be the experimental class and class VIII B is assigned to be the control class. The treatment of the PBL model was only applied to the experimental class, while the control class was taught by the teacher using a conventional learning model. This research data collection using test technique. Data analysis techniques include normality test, homogeneity test, and Independent Sample T Test. The results of this study conclude: (1) the value of Integrated Social Studies learning outcomes for class VIII students of SMP Negeri 6 Welak who are taught using the Problem based learning (PBL) model is in the 'very good' category; (2) the value of Integrated Social Studies learning outcomes for grade VIII SMP Negeri 6 Welak students who are taught using conventional learning models are in the 'good' category; (3) the value of Integrated Social Studies learning outcomes for students of class VIII SMP Negeri 6 Welak who are taught using the Problem based learning (PBL) model is significantly different from the value of Integrated Social Studies learning outcomes of students who are taught using conventional learning models.

Keywords- Learning outcomes, PBL model, conventional model, Integrated Social Studies

\section{PENDAHULUAN}

SMP Negeri 6 Welak adalah suatu lembaga pendidikan yang telah menerapkan rencana pendidikan 2013 dalam sistem pengajaran sejak sekolah ini didirikan pada tahun 2016 lalu. Hasil pertemuan dengan salah satu pendidik pelajaran IPS Terpadu VIII kemajuan belajar sesuai dengan ide pembelajaran RPP 2013 dengan pengajar sebagai fasilitator. Perhatian siswa terhadap materi yang diberikan oleh pengajar akan sangat mempengaruhi keberhasilan atau kegagalan dari ukuran pengajaran dan pembelajaran. Perhatian siswa yang lebih terkonsentrasi terhadap materi yang diberikan oleh pendidik akan membuat pertukaran informasi berlangsung lebih efektif, sehingga diyakini siklus belajar mengajar akan lebih produktif atau mudah. Adapun beberapa hal yang peneliti lihat bahwa di SMP Negeri 6 Welak memiliki beberapa permasalahan dalam pembelajaran di sana, antara lain, (1) Model pembelajaran yang sering diterapkan pendidik yaitu model pembelajaran konvensional, (2) siswa ragu-ragu untuk mengajukan pertanyaan tentang topik yang belum dipahami, (3) siswa takut untuk menyelesaikan latihan di depan kelas, sebab adanya rasa khawatir jika jawabannya tidak tepat, (4) pendidik lebih menguasai sistem pembelajaran yang sedang berlangsung di ruang belajar dan dampaknya menghasilkan siswa yang menyendiri.

Hal ini dapat dilihat dari latihan pembelajaran di kelas dimana pendidik sangat bergantung pada pembelajaran langsung dengan pendidik menjelaskan materi dan siswa cukup menyimak tanpa megikutsertakan siswa untuk mengerjakan latihan kemudian siswa mengerjakan LKS. Penggunaan model pembelajaran yang sama secara teratur dalam setiap materi yang diajarkan membuat latihan belajar siswa menjadi membosankan. Selain menggunakan model pembelajaran yang sama juga mempengaruhi hasil belajar siswa yang belum mencapai pembelajaran total. Rendahnya kerjasama antara siswa membuat siswa diminta untuk berdiskusi dengan teman sebangku, mereka akan berbincang satu dengan yang lainnya. Dengan asumsi seperti itu, tentu tidak menutup kemungkinan 
nantinya latihan belajar mereka yang tidak ideal akan mempengaruhi hasil belajar.

Hasil belajar merupakan hasil langsung berupa tingkah laku siswa setelah melalui proses belajar mengajar yang sesuai dengan materi yang dipelajarinya A.M. Sadirman (2011). Hasil belajar adalah sebagai perilaku serta hasil intelektual siswa yang dapat dilihat dan disurvei melalui tes seperti anggapan Agus Suprijono (2011) hasil belajar menggabungkan kapasitas intelektual, emosional, dan psikomotorik. Latihan pembelajaran yang memanfaatkan pembelajaran berbasis masalah memiliki beberapa keuntungan Gd. Gunantasra, (2014), yang digambarkan sebagai berikut; 1) melatih kemampuan siswa dalam menangani masalah, 2) lebih mudah mengingat materi, 3) meningkatkan pemahaman siswa terhadap materi, 4) mengembangkan lebih lanjut kemampuan yang relevan dengan dunia praktek, 5) membentuk kemampuan inisiatif dan kerjasama.

Beberapa penelitian terdahulu tentang model PBL dalam pembelajaran di sekolah terhadap hasil belajar siswa adalah sebagai berikut:

1. Widodo \& Widayanti, (2013) dengan judul Peningatan Aktivitas Belajar dan Hasil Belajar Siswa dengan Metode Problem Based Learning pada Siswa Kelas VIIA MTs Negeri Donomulyo Kulon Progo Tahun Pelajaran 2012/2013 memiliki hasil penelitian bahwa ada peningkatan gerakan siswa dan hasil belajar setelah menggunakan strategi pembelajaran berbasis isu. Perbedaan antara pengujian di atas dan eksplorasi terletak pada pengaruh model pembelajaran penelitian terdahulu terhadap hasil belajar siswa dalam hal kemampuan numerik siswa, sedangkan dalam tinjaun ini diharapkan pengaruh model pembelajaran terhadap hasil belajar

2. Wulandari \& Surjono, (2013) pada penelitiannya dengan judul PENGARUH PROBLEM-BASED LEARNING TERHADAP HASIL BELAJAR DITINJAU DARI MOTIVASI BELAJAR PLC DI SMK, menunjukkan bahwa terdapat perbedaan hasil belajar antara siswa yang dididik dengan strategi pembelajaran berbasis masalah dan yang tidak. Dimana siswa yang dididik dengan strategi pembelajaran berbasis masalah memiliki hasil belajar yang lebih tinggi dibandingkan dengan siswa yang dibimbing dengan teknik eksibisi. Perbedaan penelitian diatas dengan penelitian ini adalah penelitian sebelumnya memperoleh hasil belajar dari segi motivasi belajar PLC, sedangkan pada penelitian ini diharapkan adanya pengaruh model pembelajaran terhadap hasil belajar siswa.

3. indrianawati, (2014) dalam eksplorasinya yang berjudul STUDI KOMPARASI HASIL BELAJAR DENGAN MENGGUNAKAN MODEL PBL DAN PEMBELAJARAN KOOPERATIF TIPE STAD, menyimpulkan bahwa hasil $t$ hitung adalah sebesar 2,657 dan $t$ tabel adalah 2,000. Artinya terdapat perbedaaan hasil belajar antara kelas eksplorasi dan kelas kontrol dalam pemanfaatan model pembelajaran berbasis masalah dan model pembelajaran kooperatif tipe STAD pada kelas X Akuntansi di SMK Negeri 1 Boyalangu. Perbedaan antara eksplorasi di atas dan pengujian ini adalah model pembelajaran penelitian terdahulu untuk menentukan hasil belajar siswa menggunakan dua model pembelajaran, yaitu model pembelajaran berbasis masalah dan pembelajaran kooperatif tipe STAD, sedangkan pada penelitian ini menggunsakan model berbasis masalah dan konvensional untuk menentukan hasil belajar siswa. .

adanya kesulitan atau kegagalan siswa terhadap pelajaran IPS dapat disebabkan oleh dua variabel, yaitu faktor dalam dan faktor luar. Variabel interior adalah faktor-faktor yang berasal dari dalam diri siswa, unsur-unsur tersebut dipengaruhi oleh tiga komponen, yaitu faktor aktual tertentu, faktor mental, dan faktor kelelahan. Sedangkan faktor luar adalah faktor yang berasal dari luar siswa, dimana variabel-variabel yang mempengaruhi siswa dalam pembelajaran latihan adalah faktor keluarga, unsur sekolah, dan lingkungan 
setempat atau unsur alam. Tidak sedikit siswa yang percaya bahwa Ilmu Pengetahuan Sosial adalah pelajaran yang sangat melelahkan dan tidak sedikit siswa yang mencoba menghindari mata pelajaran ini. Salah satu alasan untuk anggapan ini adalah bahwa strategi pertunjukan pendidik membuat siswa kelelahan.

Berangkat dari landasan diatas, maka mendorong peneliti untuk mengarahkan penelitian dengan judul "PERBANDINGAN HASIL BELAJAR ANTARA PEMBELAJARAN YANG MENGGUNAKAN MODEL PROBLEM BASED LEARNING (PBL) DENGAN YANG MENGGUNAKAN MODEL PEMBELAJARAN KONVENSIONAL PADA MATA PELAJARAN IPS TERPADU SISWA KELAS VIII SMP NEGERI 6 WELAK". Penelitian ini bertujuan 1) untuk menentukan nilai hasil belajar IPS terpadu siswa yang ditampilkan menggunakan model pembelajaran berbasis masalah (PBL), 2) untuk menentukan nilai hasil belajar IPS terkoordinasi siswa yang ditampilkan menggunakan pembelajaran biasa, 3) menganalisis manfaat hasil belajar IPS Terpadu antara siswa yang ditampilkan menggunakan model Problem Based Learning (PBL) dan yang ditunjukkan menggunakan model pembelajaran biasa (konvensional).

\section{TINJAUAN PUSTAKA}

\section{Hakekat IPS Terpadu}

Muhammad Numan Somantri, (2001) "menjelaskan dan merumuskan tentang IPS di tingkat sekolah adalah suatu penyederhanaan disiplin ilmu-ilmu sosial, psikologi, filsafa, ideology negara, dan agama yang diorganisasikan dan disajikan secara ilmiah dan psikologis untuk tujuan pendidikan".

IPS merupakan interpretasi dari social studies. Ilmu sosial ditingkatkan pada sosiologi untuk tujuan penelitian yang mencakup bagian dari sejarah, masalah keuangan, teori politik, ilmu sosial, studi manusia, ilmu otak, geologi dan penalaran yang secara praktis dipilih untuk tujuan pembelajaran di sekolah dan perguruan tinggi. Sapriya, (2009) berpendapat "sejumlah teori dan gagasan Social Studies telah banyak mempengaruhi perkembangan mata pelajaran IPS sebagai bagian dari sistem kurikulum di Indonesia. National Councul for Social Studies (NCSS) merupakan salah satu lembaga dari Amerika Serikat yang mendefinisikan dan merumuskan pengertian Social Studies sebagai berikut:

Social studies is the integrated study of the social sciences and humanities to promote civic competence. Within the school program, Social Studies provides coordinated, systematic study drawing upon such disciplines as anthropology, archaeology, economics, geography, history, law, philosophy, political science, psychology, religion, and sociology, as well as appropriated content from the humanities, mathematics, and natural sciences. Savage \& Armstrong, (1996)

Berdasarkan pendapat NCSS, maka Social Studies adalah integrasi dari berbagai macam disiplin ilmu sosial dan humaniora yang dapat menumbuhkan kapasitas dan kemampuan masyarakat yang digerakkan oleh mahasiswa. Ilmu sosial terdiri dari berbagai macam sosiologi yang berbeda seperti humaniora, aspek keuangan, aspek keuangan, topografi, sejarah, hukum, masalah legislatif, agama, ilmu sosial, bahkan ilmu aritmatika dan alam.

Penilaian yang sebanding diklarifikasi oleh A. Ross, S., W. Westerfield, R., \& D. Jordan,( 2006) yang menjelaskan beberapa metodologi, substansi, dan motivasi di balik mata pelajaran investigasi ramah sebagai program pendidikan, secara spesifik:

Subject-centered approaches argue that the Social Studies curriculum derives its content and purposes from disciplines taught in higher education. Some advocates would limit Social Studies curriculum the study of traditional social sciences (e.g., anthropology, economics, political science, sociology, and psychology). Still other would inter and multidisciplinary areas such as ethnic studies, law, women's studies, cultural studies, and gay/ lesbian studies. 


\section{Model PBL (Problem Based Learning)}

PBL merupakan salah satu model Pembelajaran yang lebih banyak memusatkan peserta didik di dalam kegiatan belajar. Sebagaimana disampaikan oleh Indrianawati, (2014) yang mendeskripsikan bahwa "model PBL merupakan sebuah model pembelajaran yang bersifat student center sehingga memusatkan siswa untuk dapat menggunakan intelegensi mereka untuk dapat menyelesaikan masalah nyata yang dipecahkan dengan teman kelompoknya". Ini setara dengan penilaian Baret, T., \& Moore, S. (2011) menjelaskan dimana "PBL merupakan pembelajaran yang dihasilkan dari suatu proses pemecahan masalah yang disajikan di awal proses pembelajaran. Siswa belajar dari masalah yang nyata dalam kehidupan sehari-hari, mengorganisasi, merencana, serta memutuskan apa yang dipelajari dalam kelompok kecil". Hal yang serupa juga diungkapkan oleh Syafriana, (2017) bahwa "PBL adalah model pembelajaran yang berpusat pada siswa yang mengawali pembelajaran dengan pemberian masalah nyata kepada siswa sehingga merangsang siswa untuk belajar, kegiatan dalam model PBL didasari dari adanya kegiatan mengajukan pertanyaan atau masalah, penyelidikan autentik, bekerjasama serta menyajikan sebuah karya".

Selain itu, pendapat Gd. Gunantara, (2014) juga menyampaikan hal yang hampir sama bahwa "PBL adalah model pembelajaran yang berorientasi pada siswa sehingga memerlukan keterlibatan siswa untuk menyelesaikan masalah, model PBL dapat mendorong dan meningkatkan motivasi dan rasa ingin tahu siswa sehingga model PBL dapat menjadi suatu tempat bagi siswa untuk dapat mengembangkan cara berpikir dan keterampilan berpikir kritisnya". Keempat jurnal di atas memiliki kesamaan yang terdapat pada bagian yang menjelaskan bahwa PBL ialah model yang berpusat pada siswa yang akan lebih banyak memfokuskan siswa pada kegiatan pembelajaran. Selain memiliki kesamaan, terdapat perbedaan pada keempat jurnal di atas. Perbedaannya, jika di jurnal Gd. Gunantara, (2014) ini model PBL juga dapat mengembangkan keterampilan berpikir siswa yang didukung oleh adanya motivasi dan rasa ingin tahu siswa dalam menangani masalah nyata yang akhirnya mengakibatkan siswa mampu mengembangkan keterampilan berpikirnya. Perbedaan yang terdapat pada jurnal Gd. Gunantara, (2014) sejalan dengan pendapat Eka Eismawati, Henny Dewi \& Koeswanti, (2019)yang juga menyampaikan bahwa "PBL merupakan suatu model pembelajaran yang mampu mendorong dan mengarahkan peserta didik supaya memiliki keterampilan dalam menyelesaikan suatu masalah dalam kegiatan pembelajaran serta menekankan siswa unruk mampu mengembangkan keterampilan berpikir, sehingga mereka mampu berfikir lebih kritis".

Pendapat yang disampaikan oleh Eka Eismawati, Henny Dewi Koeswanti, (2019) mengenai PBL ini hampir sama dengan pendapat Mariya, (2019) yang menjelaskan bahwa "PBL merupakan pembelajaran yang menyajikan suatu masalah nyata yang akan mengajak siswa untuk menggunakan dan mengembangkan keterampilan berpikirnya dalam menyelesaikan masalah tersebut". Hal ini juga didukung oleh penilaian Nopia \& Sujana, (2016) yang menyampaikan bahwa "PBL merupakan model yang memiliki ciri yang identik dengan adanya suatu masalah nyata sebagai bahan bagi siswa untuk belajar menyelesaikan masalah, sehingga PBL dapat membantu siswa menumbuhkan keterampilan berpikirnya dalam proses pemecahan masalah". Penilaian ini secara praktis setara dengan apa yang disampaikan oleh Rahmadani \& Anugraheni, (2017), bahwa "PBL adalah pendekatan pembelajaran yang memanfaatkan masalah nyata sebagai suatu bahan untuk belajar, yang berguna dalam membangkitkan keterampilan berpikir dan keterampilan memecahkan masalah siswa untuk menangkap serta memahami beragam konsep dari materi yang dipelajari". Selain itu, pendapat tersebut juga hampir sama seperti pendapat yang disampaikan oleh Varia Zuliyaningsih \& Dkk, (2018) yang mengungkapkan bahwa PBL adalah sebuah model yang memiliki tujuan untuk mengarahkan siswa agar dapat mengembangkan kemampuan berpikir serta kemampuan menyelesaikan masalah, sehingga pembelajaran yang didasarkan pada permasalahan akan menuntut siswa untuk berpikir kritis dalam menyelesaikan masalah tersebut bersama kelompoknya. 
Kesamaan PBL pada jurnal Gd. Gunantara, (2014)dengan empat jurnal di atas memiliki kesamaan yang terletak pada proses pemecahan masalah dalam PBL ini, mampu mengembangkan keterampilan 55 berpikir siswa dalam menyelesaikan masalah, sehingga PBL mampu mengembangkan keterampilan berpikir kritis siswa. Kelima jurnal ini sedikit berbeda dengan pendapat yang disampaikan oleh Hadi, (2016). Pada jurnal Hadi, (2016) terdapat perbedaan pada bagian yang menyampaikan bahwa PBL selain memecahkan masalah, PBL juga akan mengarahkan siswa untuk mampu mengkonstruk serta mengintegrasi pengetahuan baru mereka melalui kegiatan pemecahan masalah. Hadi, (2016) mengungkapkan bahwa PBL adalah kegiatan pembelajaran dengan memberi masalah nyata pada siswa, pemberian masalah ini memiliki tujuan supaya siswa dapat mengkonstruk dan mengintegrasi pengetahuan yang didapatnya dalam pembelajaran. Hal yang serupa juga diungkapkan oleh Nuraini \& Kristin, (2017) yang mengungkapkan "PBL merupakan sebuah pembelajaran yang memberikan masalah nyata dengan mengembangkan pemahaman mengenai berbagai topik agar siswa belajar untuk dapat mengkonstruk kerangka masalah, menyelidiki masalah, melakukan analisis data sehingga mereka mampu mengintegrasi pengetahuan yang dimilikinya dengan pengetahuan baru". Pendapat yang hampir sama dengan jurnal di atas, disampaikan oleh Agustin, Vivin Nurul, (2013) yang menyampaikan bahwa "PBL merupakan pembelajaran yang diawali dengan memberikan latihan soal berupa suatu masalah yang berhubungan dengan kehidupan nyata siswa, melalui PBL siswa melakukan penyelesaian pada masalah tersebut untuk memperoleh dan mengintegrasi pengetahuan baru". Kesamaan yang terdapat pada ketiga jurnal di atas, terdapat pada bagian yang menjelaskan bahwa PBL disamping memecahkan masalah nyata, mengembangkan keterampilan berpikir juga mengarahkan siswa untuk dapat mengintegrasikan pengetahuan yang dimilikinya dengan pengetahuan baru yang mereka dapat dari kegiatan memecahkan masalah.

Berdasarkan analisis tersebut, hal ini cenderung dapat disimpulkan bahwa model PBL merupakan salah satu model pembelajaran yang memulai pembelajaran dengan memberikan persoalan-persoalan nyata kepada siswa. Model PBL ini memusatkan siswa untuk ikut terlibat pada setiap kegiatan pembelajaran, dimana dalam tindakan pembelajaran ini dibutuhkan siswa yang memiliki pilihan untuk membangun masalah, mengajukan pertanyaan, melakukan penyelidikan serta menganalisis data sehingga diperoleh suatu karya yang dapat mereka tampilkan. Melalui proses pemecahan masalah yang ada di dalam model PBL ini dapat membuat siswa mampu mengembangkan keterampilannya dalam berfikir sehingga mereka dapat berfikir lebih kritis untuk dapat memecahkan masalah dan hal ini akan berdampak pada informasi siswa yang dapat mereka koordinasikan antara informasi yang mereka miliki saat ini dengan informasi baru yang mereka peroleh dalam proses pemecahan masalah.

\section{Model Pembelajaran Konvensional}

Merupakan "kondisi pembelajaran yang hanya dilakukan dengan satu arah, yaitu dari guru kepada siswa. Dalam konteks pembelajaran konvensional, siswa sekaligus mengerjakan dua kegiatan yaitu mendengarkan dan mencatat" Sumitro,(2017).

Menurut Ningsih (2019), pembelajaran konvensional merupakan "model pembelajaran tradisional atau disebut juga dengan metode ceramah, karena sejak dulu metode ini telah dipergunakan sebagai alat komunikasi lisan antara guru dengan siswa dalam proses pembelajaran". Terlebih lagi, pembelajaran tradisional digambarkan dengan alamat-alamat yang disertai dengan penjelasan, seperti pembagian tugas, dan kegiatan.

Menurut Hamalik (2013), terdapat beberapa karakteristik dari pembelajaran konvensional, yaitu "siswa tidak mengetahui tujuan mereka belajar pada hari itu, guru biasanya mengajar berpedoman pada buku, tes atau evaluasi biasanya bersifat sumatif dengan maksud untuk mengetahui perkembangan siswa, dan siswa harus mengikuti cara 
belajar yang dipilih guru dengan patuh mempelajari urutan yang ditetapkan dan kurang sekali mendapatkan kesempatan untuk menyatakan pendapatnya". Siswa yang memperoleh pengalaman tersebut akan berpandangan bahwa belajar merupakan suatu perkembangan aturan yang ditetapkan oleh pengajar dan harus diikuti oleh siswa, sebagaimana tugas pendidik sebagai sumber belajar yang mendasar. Dengan demikian, anak-anak terhindar dari berbagai sumber informasi yang sebenarnya bagus.

\section{Hasil Belajar}

Kingsley (2009) mengelompokkan tiga point penting hasil belajar, yakni “(a) keterampilan dan kebiasaan, (b) pengetahuan dan pengertian, (c) sikap dan cita-cita, masing-masing jenis hasil belajar dapat diisi dengan bahan yang telah ditettapkan dalam kurikulum". Untuk sementara, Gagne memisahkan lima kelas hasil belajar, yaitu (a) data verbal, (b) kemampuan ilmiah, (c) teknik intelektual, (d) perspektif, dan (e) kemampuan mesin. Dalam kerangka pelatihan publik, rencana tujuan instruktif, baik target kurikuler maupun informatif, menggunakan urutan pengambilan hasil dari Benjamin Sprout yang secara komprehensif memisahkannya menjadi tiga bidang, yaitu spesifik ruang intelektual, emosional, dan psikomotorik.

\section{METODE}

Metode yang digunakan dalam penelitian ini adalah kuantitatif dengan rancangan quasi eksperiment design. Pada kelas tes perlakuan diterapkan modal belajar PBL (Problem based learning), sedangkan pada kelas kontrol diterapkan sebagai bimbingan langsung yang biasanya digunakan oleh guru pada langkah pembelajaran sebelumnya. Adapun tujuannya ingin mengetahui adanya pengaruh apabila diterapkan metode berupa model pembelajaran PBL. Populasi pada penelitian ini adalah seluruh siswa kelas VIII SMP Negeri 6 Welak 2020/2021, yang totalnya berjumlah 50 peserta didik dimana terdiri dari masing-masing kelas A dan B yaitu, 25 peserta didik. Sampling menggunakan total sampling, dengan tujuan agar semua individu dari populasi dialokasikan untuk menjadi contoh, dimana kelas VIII A diturunkan menjadi kelas uji coba dan kelas VIII B diangkat menjadi kelas kontrol. Bermacam-macam informasi dari eksplorasi ini menggunakan teknik tes berupa soal. Metode pemeriksaan informasi meliputi uji keteraturan, uji homogenitas, dan uji $t$. Alat pemeriksaan menggunakan SPSS 23.0 for Windows.Teknik analisis data meliputi uji normalitas, uji homogenitas, dan uji independent sample T test. Alat analisis menggunakan SPSS 23.0 for Windows.

\section{PEMBAHASAN}

\section{Uji Tingkat Kesukaran Soal}

Untuk menentukan tingkat kesulitan dari setiap soal terlebih dahulu peneliti menganalisis tiap butir soal yang telah dijawab oleh siswa uji coba instrumen. Adapun kriteria pengambilan dalam taraf uji kesukaran yaitu "0,00-0,30 berkategori sulit, 0,30-0,70 berkategori sedang dan 0,70-1,00 berkategori mudah" (Anas Sudijono, 2011). Dengan demikian, hasil perhitungan menggunakan Microsoft Excel peneliti menyimpulkan berdasarkan tes yang dibuat peneliti berupa soal dengan tingkat kesukaran seperti pada Tabel 4.1 di bawah ini.

Tabel 4. 1 Hasil Uji Tingkat Kesukaran Soal

\begin{tabular}{|c|c|c|c|c|c|}
\hline $\begin{array}{l}\text { No } \\
\text { soal }\end{array}$ & $\begin{array}{l}\text { Tingkat } \\
\text { kesukaran }\end{array}$ & Kriteria & $\begin{array}{l}\text { No. } \\
\text { Soal }\end{array}$ & $\begin{array}{l}\text { Tingkat } \\
\text { Kesukaran }\end{array}$ & Kriteria \\
\hline 1 & 0,50 & Sedang & 14 & 0,54 & Sedang \\
\hline 2 & 0,50 & Sedang & 15 & 0,54 & Sedang \\
\hline 3 & 0,71 & Mudah & 16 & 0,50 & Sedang \\
\hline
\end{tabular}


Perbandingan Model Problem Based Learning (PBL) dan Model Pembelajaran Konvensional terhadap Hasil Belajar IPS Terpadu Siswa SMP Negeri 6 Welak

\begin{tabular}{lll}
\hline $\begin{array}{l}\text { No } \\
\text { soal }\end{array}$ & $\begin{array}{l}\text { Tingkat } \\
\text { kesukaran }\end{array}$ & Kriteria \\
\hline 4 & 0,50 & Sedang \\
\hline 5 & 0,63 & Sedang \\
\hline 6 & 0,54 & Sedang \\
\hline 7 & 0,50 & Sedang \\
\hline 8 & 0,58 & Sedang \\
\hline 9 & 0,46 & Sedang \\
\hline 10 & 0,50 & Sedang \\
\hline 11 & 0,50 & Sedang \\
\hline 12 & 0,58 & Sedang \\
\hline 13 & 0,54 & Sedang \\
\hline
\end{tabular}

\begin{tabular}{lll}
\hline $\begin{array}{l}\text { No. } \\
\text { Soal }\end{array}$ & $\begin{array}{l}\text { Tingkat } \\
\text { Kesukaran }\end{array}$ & Kriteria \\
\hline 17 & 0,54 & Sedang \\
\hline 18 & 0,46 & Sedang \\
\hline 19 & 0,46 & Sedang \\
\hline 20 & 0,58 & Sedang \\
\hline 21 & 0,46 & Sedang \\
\hline 22 & 0,50 & Sedang \\
\hline 23 & 0,54 & Sedang \\
\hline 24 & 0.63 & Sedang \\
\hline 25 & 0,42 & Sedang \\
\hline
\end{tabular}

(Sumber: Data diolah, 2021)

Dilihat dari Tabel 4.1 bahwa dari 25 butir soal pilihan ganda hanya sebanyak 1 butir soal yang dapat digolongkan kriteria mudah, sedangkan sisa soal (24) lainnya termasuk kriteria sedang. Nilai ratarata tingkat kesukaran soal yaitu 0,53 yang juga merupakan termasuk kriteria sedang.

\section{Uji Daya Pembeda Soal}

Pertanyaan seharusnya dapat diterima, jika pertanyaan dapat ditangani secara akurat oleh siswa berkapasitas tinggi. Untuk memutuskan kekuatan khusus dari pertanyaan dalam tinjauan ini, terlebih dahulu peneliti menganalsis tes berupa soal yang sudah dikerjakan peserta didik menggunakan Microsoft excel. Kemudian peneliti mengurutkan skor yang diperoleh dan membagi dalam dua kelompok yaitu kelompok atas dan kelompok bawah. Angka yang menunjukan sejauh mana kekuatan yang tidak adil dikenal sebagai catatan pemisahan atau terpotong D. Berdasarkan hasil analisis perhitungan uji daya pembeda soal dengan melihat kriteria daya pembeda, maka diperoleh hasil sebagai berikut.

Tabel 4. 2 Analisis Daya Pembeda Soal

\begin{tabular}{|c|c|c|c|c|c|}
\hline $\begin{array}{l}\text { No } \\
\text { soal }\end{array}$ & $\begin{array}{l}\text { Daya } \\
\text { pembeda }\end{array}$ & Kriteria & No. Soal & Daya pembeda & Kriteria \\
\hline 1 & 0,83 & Sangat Baik & 14 & 0,75 & Sangat Baik \\
\hline 2 & 0,67 & Baik & 15 & 0,75 & Sangat Baik \\
\hline 3 & 0,42 & Baik & 16 & 0,67 & Baik \\
\hline 4 & 0,83 & Sangat Baik & 17 & 0,42 & Baik \\
\hline 5 & 0,58 & Baik & 18 & 0,75 & Sangat Baik \\
\hline 6 & 0,75 & Sangat Baik & 19 & 0,58 & Baik \\
\hline 7 & 0,67 & Baik & 20 & 0,67 & Baik \\
\hline 8 & 0,83 & Sangat Baik & 21 & 0,75 & Sangat Baik \\
\hline 9 & 0,42 & Baik & 22 & 0,50 & Baik \\
\hline 10 & 0,83 & Sangat Baik & 23 & 0,58 & Baik \\
\hline 11 & 0,67 & Baik & 24 & 0,42 & Baik \\
\hline 12 & 0,50 & Baik & 25 & 0,50 & Baik \\
\hline
\end{tabular}

(Sumber: Data diolah, 2021) 
Dilihat dari hasil analisis soal sebanyak 25 soal pilihan ganda terdapat pada tabel 4.4 di atas dapat disimpulkan bahwa seluruh butir soal termasuk kategori baik hingga sangat baik. Kategori soal sangat baik sebanyak 10 soal sedangkan sisanya berkategori baik. Untuk rata-rata nilai daya pembeda soal dari 25 item termasuk dalam kategori baik untuk digunakan dalam pengujian dengan nilai sebesar 0,64 .

\section{Uji Validitas Soal}

Uji validitas digunakan untuk membuktikan valid atau tidaknya butir-butir soal tes. Butir soal yang tidak valid di buang dan tidak dipakai, sementara untuk butir soal yang valid dipakai untuk tes pada kelompok yang akan diuji. Berikutnya adalah informasi berupa data hasil perhitungan validasi butir soal.

Tabel 4.3 Analisi validasi butir soal

\begin{tabular}{|c|c|c|c|c|c|c|c|}
\hline \multirow{2}{*}{$\begin{array}{l}\text { No } \\
\text { soal }\end{array}$} & \multicolumn{3}{|c|}{ Validitas } & \multirow{2}{*}{$\begin{array}{l}\text { No } \\
\text { soal }\end{array}$} & \multicolumn{3}{|c|}{ Validitas } \\
\hline & rhitung & rtabel & Ket. & & rhitung & rtabel & Ket. \\
\hline 1 & 0,899 & 0.404 & Valid & 14 & 0,831 & 0.404 & Valid \\
\hline 2 & 0,621 & 0.404 & Valid & 15 & 0,761 & 0.404 & Valid \\
\hline 3 & 0,552 & 0.404 & Valid & 16 & 0,691 & 0.404 & Valid \\
\hline 4 & 0,850 & 0.404 & Valid & 17 & 0,432 & 0.404 & Valid \\
\hline 5 & 0,697 & 0.404 & Valid & 18 & 0,795 & 0.404 & Valid \\
\hline 6 & 0,741 & 0.404 & Valid & 19 & 0,536 & 0.404 & Valid \\
\hline 7 & 0,730 & 0.404 & Valid & 20 & 0,706 & 0.404 & Valid \\
\hline 8 & 0,827 & 0.404 & Valid & 21 & 0,755 & 0.404 & Valid \\
\hline 9 & 0.466 & 0.404 & Valid & 22 & 0,551 & 0.404 & Valid \\
\hline 10 & 0,830 & 0.404 & Valid & 23 & 0,631 & 0.404 & Valid \\
\hline 11 & 0,720 & 0.404 & Valid & 24 & 0,440 & 0.404 & Valid \\
\hline 12 & 0,585 & 0.404 & Valid & 25 & 0,553 & 0.404 & Valid \\
\hline 13 & 0,721 & 0.404 & Valid & & & & \\
\hline
\end{tabular}

(Sumber: Data diolah, 2021)

Tabel 4.3 di atas menunjukkan bahwa semua item soal tersebut dinyatakan valid. Hal ini dikarenakan rhitung $>$ rtabel. rtabel merupakan sebuah angka dalam tabel yang bisa dipakai guna memperoleh hasill uji kebenaran suatu instrumen penelitian. Penelitian ini diketahui jumlah siswa kelas IX IPS yang digunakan adalah sebanyak 24 dengan signifikan $5 \%$ pada distribusi nilai rabel-nya dan 25 soal pilihan ganda dengan nilai total masing-masing nomor soal yaitu 1 . Rumus untuk mencari rabel yaitu $\mathrm{df}=\mathrm{N}-2$, karena jumlah siswa yang melakukan uji coba instrumen sebanyak 24 maka nilai $\mathrm{N}=24-2=22$. Sehingga dapat diketahui nilai rtabel pada penelitian ini yaitu 0,404 . Setelah rtabel diketahui, selanjutnya soal-soal tersebut dianalisis menggunakan SPSS 23 for windows untuk mencari rhtung dan guna memperoleh soal yang menyatakan soal tersebut valid atau tidak. Berdasarkan hasil perhitungan uji validitas menggunakan SPSS 23 For Windows, maka seluruh item soal dinyatakan valid. Hal ini dikarenakan harga rhitung $>$ rtabel $(0,404)$ yang artinya adanya korelasi antar variabel yang dihubungkan.

\section{Uji Reabilitas Soal}

Uji reabilitas digunakan untuk menentukan tingkat konsistensi jawaban tepat. Sebelum dilakukan pengujian reliabilitas harus adanya dasar pengambilan keputusan yaitu alpha sebesar 0,60, sebaliknya apabila nilai Cronbach Alpha $<0,60$ maka variabel yang teliti tidak bisa dikatakan reliabel, Cronbach Alpha merupakan model internal consistency score berdasarkan korelasi rata-rat antara 
butir-butir yang equivalen. Berikut ini tabel hasil perhitungan uji Realibitas menggunakan SPSS 23 for windows.

Tabel 4. 4 Hasil Uji Reliablitas

\begin{tabular}{ll}
\hline Cronbach Alpha & N of Items \\
\hline 0,951 & 25 \\
\hline
\end{tabular}

(Sumber: Data diolah, 2021)

Dengan demikian, tabel hasil perhitungan uji realibilitas menggunakan SPSS 23 for windows, dapat diketahui nilai Cronbach Alpha sebesar 0,951 dengan N of Item 25, nilai Cronbach Alpha terlihat lebih tinggi dari pada nilai alpha dikarenakan 0,951 >0,60, maka bisa disimpulkan bahwa soal-soal tersebut dinyatakan realiabel atau dapat dipercaya.

\section{Hasil Uji Normalitas}

Kriteria pengambilan keputusan dari hasil uji normalitas ini yaitu jika nilai sig $>0,05$ maka data berdistribusi normal dan jika nilai sig $<0,05$ maka data tidak berdistribusi normal. Proses pelaksanaan uji normalitas dilakukan dengan menggunakan bantuan SPSS 23.0 for Windows. Tabel 4.7 berikut ini menunjukkan rangkuman output SPSS hasil uji normalitas melalui metode Uji Kolmogorovsmirnov.

Tabel 4.5 Hasil Uji Normalitas Kolmogorov-smirnov

\begin{tabular}{lllll}
\hline \multicolumn{4}{l}{ Tests of Normality } & \multicolumn{4}{l}{} \\
\cline { 3 - 5 } & \multirow{2}{*}{ Kelompok } & Statistic & Df & Sig. \\
\hline \multirow{2}{*}{ Skor } & Eksperimen & 0.152 & 25 & 0.139 \\
\cline { 2 - 5 } & Kontrol & 0.168 & 25 & 0.067 \\
\hline
\end{tabular}

a. Liliefors Significance Correction

(Sumber: Data diolah, 2021)

Berdasarkan Tabel 4.1 di atas, diketahui output SPSS hasil dari Test of Normality menunjukkan nilai signifikansi (sig) untuk kelompok eksperimen 0,139 dan nilai sig kelompok kontrol sebesar 0,067. Oleh karena nilai sig kedua kelompok >0,05, maka dapat disimpulkan bahwa data berdistribusi normal.

\section{Hasil Uji Homogenitas}

Uji homogenitas ini sebagai prasyarat sebelum dilakukannya uji Independent Samples T Test agar dapat memenuhi asumsi homogenitas. Uji homogenitas dalam penelitian ini dilakukan melalui uji One Way ANOVA, yang prosesnya dilakukan dengan menggunakan bantuan SPSS 23.0 for Windows. Asumsi yang mendasari dalam Analisis of Varians (ANOVA) ialah bahwa varian dari beberapa kelompok data yang independen adalah sama. Adapun dasar atau pedoman pengambilan keputusan uji homogenitas ini adalah jika signifikansi $>0,05$ maka Ho diterima (varian sama) dan jika signifikansi < 0,05 maka $\mathrm{H}_{0}$ ditolak (varian berbeda).

Tabel 4. 6 Hasil Uji Homogenitas One Way ANOVA

\begin{tabular}{lllll}
\hline . Test of Homogeneity of Variances & & & \\
\hline . Skor posttest & . & . & . \\
\hline . Levene Statistic & 0. df1 & 1. df2 & 2. Sig. \\
\hline
\end{tabular}


Perbandingan Model Problem Based Learning (PBL) dan Model Pembelajaran Konvensional terhadap Hasil Belajar IPS Terpadu Siswa SMP Negeri 6 Welak

\begin{tabular}{llll}
\hline $\mathbf{3 . 0 . 0 0 8}$ & 4.1 & 5.48 & 6.0 .930 \\
\hline (Sumber:
\end{tabular}

(Sumber: Data diolah, 2021)

Berdasarkan data yang tercantum pada Tabel 4.2 di atas, diketahui bahwa nilai signifikansi pada output Test of Homogeneity of Variances melalui One Way ANOVA adalah 0,930. Oleh karena nilai sig $(0,930)>0,05$ maka $\mathrm{H}_{0}$ diterima. Dengan demikian, maka dapat disimpulkan bahwa kelompok data posttest hasil belajar IPS Terpadu (eksperimen dan kontrol) memiliki varian yang sama, sehingga asumsi homogenitas data pada penelitian ini telah terpenuhi.

\section{Hasil Uji T}

Uji Independent Samples T Test (Uji T Sampel Bebas) dilakukan untuk menganalisis perbedaan hasil belajar antara siswa yang diajar menggunakan model PBL dengan model pembelajaran konvensional pada mata pelajaran IPS Terpadu kelas VIII SMP Negeri 6 Welak. Uji Independent Samples T Test dilakukan setelah diperoleh data posttest seluruh siswa dari kelompok eksperimen dan kontrol.

Pengolahan data (Independent Samples T Test) dilakukan dengan software SPSS 23.0 for Windows. Ada dua output SPSS hasil uji Independent Samples T Test, yang pertama statistik kelompok data bebas seperti yang tercantum dalam Tabel 4.9 di bawah ini.

Tabel 4. 7 Group Statistics

\begin{tabular}{llllll}
\hline & Kelompok & $\mathrm{N}$ & Mean & Std. Deviation & Std. Error Mean \\
\hline Skor posttest & Eksperimen & 25 & 88.52 & 5.702 & 1.140 \\
\cline { 2 - 6 } & Kontrol & 25 & 75.20 & 6.110 & 1.222 \\
\hline
\end{tabular}

(Sumber: Data diolah, 2021)

Tabel 4.3 di atas merupakan output pertama hasil uji Independent Samples T Test melalui SPSS. Output tersebut menjelaskan tentang satistik kelompok data. Dari tabel tersebut diketahui bahwa jumlah data (N) skor posttest hasil belajar IPS Terpadu pada kedua kelompok berjumlah 25. Hal tersebut berarti bahwa seluruh data telah lengkap dan telah dimasukkan ke dalam analisis tersebut sehingga tidak ada data missing. Dari Tabel 4.9 juga diketahui mean (rata-rata skor) posttest kelompok eksperimen sebesar 88,52 dan mean posttest kelompok kontrol sebesar 75,20. Hal tersebut menjelaskan bahwa rata-rata hasil belajar IPS Terpadu siswa kelompok eksperimen (diajar menggunakan model PBL) lebih tinggi daripada rata-rata hasil belajar IPS Terpadu siswa kelompok kontrol (diajar menggunakan model pembelajaran konvensional)

Tabel 4. 8 Hasil Uji Independent Samples T Test

\begin{tabular}{|c|c|c|c|c|}
\hline & & \multicolumn{3}{|c|}{ Skor posttest } \\
\hline & & $\begin{array}{l}\text { Equal } \\
\text { assumed }\end{array}$ & variance & $\begin{array}{l}\text { Equal variance } \\
\text { not assumed }\end{array}$ \\
\hline \multirow{2}{*}{$\begin{array}{l}\text { Levene's Test fo } \\
\text { Equality of Variance }\end{array}$} & $\mathrm{F}$ & 0.008 & & \\
\hline & Sig. & 0.930 & & \\
\hline \multirow{6}{*}{$\begin{array}{l}\text { t-test for Ec } \\
\text { Means }\end{array}$} & $\mathrm{T}$ & 7.969 & & 7.969 \\
\hline & Df & 48 & & 47.772 \\
\hline & Sig. (2-tailed) & 0.000 & & 0.000 \\
\hline & Mean difference & 13.320 & & 13.320 \\
\hline & Std. error difference & 1.671 & & 1.671 \\
\hline & 95\% Confidence inter- Lower & 9.959 & & 9.959 \\
\hline
\end{tabular}


Perbandingan Model Problem Based Learning (PBL) dan Model Pembelajaran Konvensional terhadap Hasil Belajar IPS Terpadu Siswa SMP Negeri 6 Welak

\begin{tabular}{rrrr}
\hline nal of the difference & Upper & 16.681 & 16.681 \\
\hline
\end{tabular}

(Sumber: Data diolah, 2021)

Berdasarkan data yang tercantum pada Tabel 4.3 di atas, maka dapat diuraikan langkah-langkah pengujian hipotesis berdasarkan signifikansi hasil uji Independent Samples $t$ Test seperti yang dikemukakan oleh Priyatno, (2016), sebagai berikut:

1. Menentukan $\mathrm{H}_{0}$ dan $\mathrm{Ha}$

Ho : Nilai hasil belajar IPS Terpadu siswa yang diajar menggunakan model Problem based learning (PBL) tidak berbeda signifikan dengan nilai hasil belajar IPS Terpadu siswa yang diajar menggunakan model pembelajaran konvensional.

Ha : Nilai hasil belajar IPS Terpadu siswa yang diajar menggunakan model Problem based learning (PBL) berbeda signifikan dengan nilai hasil belajar IPS Terpadu siswa yang diajar menggunakan model pembelajaran konvensional.

2. Menentukan taraf signifikansi

Dari output SPSS yang tercantum dalam Tabel 4.3 diketahui nilai Sig. (2-tailed) adalah 0,000.

3. Pengambilan keputusan

Kriteria pengambilan keputusan $\mathrm{H}_{0}$, yaitu:

- $\quad$ Jika sig > 0,05 maka $\mathrm{H}_{0}$ diterima dan Ha ditolak.

- $\quad$ Jika sig $\leq 0,05$ maka Ho ditolak dan Ha diterima.

4. Kesimpulan

Diketahui nilai sig $(0,000)<0,05$ maka Ho ditolak dan Ha diterima.

Berdasarkan uraian di atas, maka dapat disimpulkan nilai hasil belajar IPS Terpadu siswa yang diajar menggunakan model Problem based learning (PBL) berbeda signifikan dengan nilai hasil belajar IPS Terpadu siswa yang diajar menggunakan model pembelajaran konvensional.

\section{Hasil Belajar IPS Terpadu Siswa Sebelum Diberi Perlakuan}

Berdasarkan hasil analisis data skor pretest kelompok eksperimen dan kontrol diketahui mean skor pretest kelompok A adalah 52,960, di mana skor tertinggi yang dicapai siswa adalah 64 dan skor terendahnya 40. Sementara itu, mean skor pretest kelompok B adalah 52,160, di mana skor tertinggi yang dicapai oleh siswa adalah 64 dan skor terendah adalah 44. Berdasarkan data pretest kedua kelompok di atas, nampak bahwa dalam kehidupan sehari-hari dasar hasil belajar mata pelajaran IPS antar siswa kelompok uji dan kontrol sangat sedikit berbeda atau hampir sama.

Hal tersebut dikarenakan pretest diberikan kepada siswa sebelum mereka, khususnya siswa kelompok eksperimen diajar melalui modal PBL, dimana ketika itu kegiatan pembelajaran yang diselenggarakan guru masih menggunakan model konvensional, baik pada siswa kelompok eksperimen maupun kontrol. Guru belum mengaktifkan siswa untuk belajar secara penuh, karena guru mengajar siswa cenderung mengandalkan teknik berceramah, tanya jawab dengan siswa dan kegiatan pembelajaran lebih didominasi oleh guru (teacher centered). Akibatnya, hanya sedikit siswa yang berpartisipasi aktif dalam aktivitas pembelajaran di kelas. Dengan demikian, ukuran pembelajaran biasa tidak mendorong siswa untuk mengambil bagian yang berfungsi dalam pembelajaran, dengan tujuan agar hasil belajar IPS Terpadu yang dicapai, baik oleh siswa kelompok eksperimen maupun kontrol pun kurang memuaskan.

\section{Hasil Belajar IPS Terpadu Siswa Sesudah Diberi Perlakuan}

Berdasarkan hasil analisis nilai posttest kelompok uji coba dan kelompok kontrol, diketahui bahwa nilai normal posttest kelompok uji coba adalah 88.520, dimana nilai paling tinggi yang dicapai 
siswa adalah 97 dan nilai terkecil adalah 78. Sementara itu, rata-rata skor posttest kelompok kontrol hanya 75,200, di mana nilai paling tinggi yang dicapai siswa adalah 88 dan nilai terendahnya 64 . Berdasarkan data posttest kedua kelompok di atas, maka dapat dikemukakan bahwa hasil belajar IPS siswa kelompok uji coba (dididik melalui model pembelajaran PBL) lebih tinggi daripada hasil belajar IPS siswa kelompok kontrol (dibimbing melalui model pembelajaran biasa).

Hal tersebut karena model PBL yang diterapkan kepada siswa kelompok eksperimen menekankan siswa pada proses kegiatan pembelajaran yang mengarah pada upaya untuk menyelidiki informasi atau masalah dan upaya mendapatkan tanggapan dari suatu permasalahan yang diajukan dengan menggunakan cara berpikir secara logis, kritis dan analisis dalam menyelesaikan permasalahannya. Oleh karena itu, maka kemampuan berpikir siswa kelompok eksperimen lebih terlatih dan mereka lebih aktif dalam proses belajarnya, sehingga hasil belajarnya sangat memuaskan. Sementara itu, di kelas kontrol pendidik justru menggunakan model pembelajaran biasa, yakni belum mengaktifkan siswa untuk belajar secara penuh yaitu pembelajaran langsung. Guru hanya berceramah, tanya jawab dengan siswa dan kegiatan pembelajaran lebih didominasi oleh guru, serta lebih sedikit melibatkan peserta didik pada aktivitas pembelajaran berlangsung. Dengan demikian, sistem pembelajaran pada kelompok biasa tidak mendorong siswa untuk berperan aktif dalam pembelajaran, sehingga hasil belajar yang dicapai kurang baik.

Perbandingan Hasil Belajar IPS Terpadu Antara Siswa yang Diajar Menggunakan Model PBL dengan Siswa yang Diajar Menggunakan Model Konvensional.

Berdasarkan hasil uji independent sample $t$ test dan pengujian hipotesis, diketahui nilai sig $\mathrm{t}(0,000)<$ 0,05, sehingga $\mathrm{H}_{0}$ ditolak dan Ha diakui. Dengan demikian, cenderung beralasan bahwa nilai hasil belajar IPS siswa yang ditampilkan menggunakan model pembelajaran berbasis masalah (PBL) pada dasarnya unik dibandingkan dengan nilai hasil belajar IPS siswa yang sedang belajar ditampilkan dengan memanfaatkan model pembelajaran konvensional.

Perbedaan hasil belajar IPS Terpadu antara kelompok tes dan kelompok biasa dapat dilihat dari nilai siswa, baik pada pretest maupun posttest. Hasil dari ulasan ini menunjukkan bahwa nilai normal hasil belajar IPS siswa kelas eksperimen yang ditampilkan menggunakan model PBL semakin meningkat dari pretest ke posttest, yaitu rata-rata skor pretest hanya 52,960, lalu meningkat drastis pada posttest sebesar 88,520. Hasil di atas membuktikan bahwa secara deskriptif penerapan model PBL berpengaruh positif bagi hasil belajar IPS Terpadu siswa kelompok eksperimen. Kondisi tersebut jauh berbeda jika membandingkan dengan siswa kelompok kontrol yang dalam penelitian ini diajar menggunakan model pembelajaran konvensional. Meskipun skor tes hasil belajar IPS Terpadu siswa kelompok kontrol juga meningkat dari pretest ke posttest, yaitu mean nilai pretest $(52,160)$ dan posttest $(75,200)$, namun peningkatannya tidak signifikan dibanding siswa kelompok kelas A yang proses pembelajarannya menerapkan model berbasis masalah.

Perbedaan hasil belajar IPS Terpadu antara siswa kelompok eksperimen yang diajar melalui model PBL dengan siswa kelompok kontrol yang diajar melalui model pembelajaran konvensional dipengaruhi oleh beberapa hal atau kondisi. Pertama, teknik-teknik dalam langkah-langkah model. Pada dasarnya langkah pembelajaran PBL ini berpusat pada keberadaan masalah dan menemukan jawaban untuk mengatasi masalah tersebut. lingkungan pembelajaran yang harus disiapkan dalam pembelajaran berbasis masalah ini adalah lingkungan pembelajaran terbuka sehingga dapat menggarisbawahi gerakan siswa. Setara dengan pendapat Fogarty (2011) bahwa :PBL ini dimulai dengan masalah yang tidak terstruktur, dalam artian bahwa masalah yang ada yaitu sesuatu yang kacau". Dari masalah ini, para siswa memanfaatkan perbedaan wawasan mereka melalui percakapan dan analisis untuk memutuskan masalah utama yang ada.

Kedua, model PBL mempunyai beberapa manfaat yang berbeda dibandingkan dengan model biasa. Kelebihan dari model PBL adalah (1) siswa benar-benar memahami atau memahami bahwa 
keberhasilan perkumpulan bergantung pada keberhasilan individunya; (2) siswa memiliki kemampuan sosial, khususnya siswa akan memahami bahwa perkumpulan tidak akan berjalan dengan baik jika siswa tidak memiliki kemampuan sosial. Senada dengan pendapat Rusman (2010) yang mengatakan bahwa "dalam memecahkan suatu masalah diperlukan kerjasama antara kelompok agar proses pembelajaran berjalan dengan baik".

Ketiga, pelaksanaan model PBL dilengkapi dengan aktivitas diskusi antar siswa yang ditunjang oleh Lembar Kerja Siswa (LKS). Dengan dibentuknya kelompok dalam model PBL maka siswa kelompok eksperimen secara bersama-sama dapat menyelesaikan atau menemukan solusi dari masalahmasalah yang diajukan. Hal ini persis yang diungkapkan Rusman (2010) yaitu "pembelajaran kelompok merupakan pembelajaran yang beranggotakan empat sampai enam orang dengan struktur kelompok yang bersifat heterogen dengan tujuan agar proses pembelajaran yang ditentukan bisa tercapai". Jadi, dengan model PBL dalam pembelajaran IPS, siswa dapat mengajukan pertanyaan, mencari jawaban, mendapatkan balasan, balasan yang luar biasa yang berkaitan dengan pembelajaran IPS serta diterapkan dalam lingkungan tempat tinggalnya.

Hal tersebut berbeda dengan aktivitas yang dilakukan siswa kelompok biasa yang dilatih melalui pembelajaran konvensional. Hal ini disebabkan pada kelas biasa guru masih menggunakan pembelajaran yang belum mengaktifkan siswa untuk belajar secara penuh yaitu pembelajaran langsung. Guru hanya berceramah, tanya jawab dengan siswa dan kegiatan pembelajaran lebih didominasi oleh guru serta lebih sedikit melibatkan siswa dalam aktivitas pembelajaran berlangsung. Dalam proses pembelajaran siswa hanya datang, duduk, diam, mendengarkan, dan menulis materi yang disampaikan oleh guru. Sehingga pada proses pembelajaran tersebut tidak memotivasi peserta didik agar ikutserta secara aktif di dalam pembelajaran dan hasil belajar yang dicapai tidak memuaskan

\section{KESIMPULAN}

Berdasarkan hasil penyelidikan dan percakapan seperti yang telah diuraikan pada bagian sebelumnya, maka akhir dari tinjauan ini dapat dikemukakan sebagai berikut: 1) Nilai hasil belajar IPS siswa kelas VIII SMP Negeri 6 Welak yang ditampilkan memanfaatkan model Problem Based Learning (PBL) termasuk kategori sangat baik', 2) Nilai hasil belajar IPS siswa kelas VIII SMP Negeri 6 Welak yang ditunjukkan menggunakan model pembelajaran biasa termasuk kategori "baik", 3) Nilai Koordinasi Hasil belajar IPS Terpadu siswa kelas VIII SMP Negeri 6 Welak yang ditunjukkan menggunakan model pembelajaran berbasis masalah (PBL) pada dasarnya tidak sama dengan nilai hasil belajar IPS siswa yang ditampilkan menggunakan model pembelajaran biasa.

\section{DAFTAR PUSTAKa}

A. Ross, S., W. Westerfield, R., \& D. Jordan, B. (2006). Fundamentals of Corporate Finance. New York: McGraw-Hill Irwin.

Agus Suprijono. (2011). Model-Model Pembelajaran. Jakarta: Gramedia Pustaka Jaya.

A.M. Sardiman. (2011). Interaksi dan Motivasi Belajar Mengajar. Jakarta: Rajawali Press.

Anas Sudijono. (2011). Pengantar Evaluasi Pendidikan. Jakarta: PT Rajagrafindo Persada.

Baret, T., \& Moore, S. (2011). New Approaches to Problem-based Learning: Revitalising your Practice in Higher Education. New York: Routledge.

Eka Eismawati, Henny Dewi Koeswanti, E. H. R. (2019). Peningkatkan Hasil Belajar Matematika Siswa Kelas 4 Sd Melalui Model Pembelajaran Problem Based Learning. Justek: Jurnal Sains Dan Teknologi, 1(1), 120. https://doi.org/10.31764/justek.v1i1.416

Gd. Gunantara, M. S. \& P. N. R. (2014). Penerapan Strategi Pembelajaran Problem Based Learning 
Untuk Meningkatkan Kemampuan Pemecahahan Masalah Matematis Siswa Kelas IV. Kreano, Jurnal Matematika Kreatif-Inovatif, 10(2), 146-152. https://doi.org/10.15294/kreano.v10i2.19671

Hadi, F. R. (2016). Penerapan Pembelajaran Problem Based Learning (Pbl) Untuk Meningkatkan Hasil Belajar Matematika Siswa Kelas Iv. Profesi Pendidikan Dasar, 3(2), 80. https://doi.org/10.23917/ppd.v3i2.2925

Hamalik, O. (2013). Proses Belajara Mengajar. Jakarta : Bumi Aksara, 2013.

Indrianawati, I. (2014). Studi Komparasi Hasil Belajar Siswa Menggunakan Model PBL dan Model Pembelajaran Kooperatif Tipe STAD. 1-11.

Kingsley, Howard, D. S. N. (2009). Penilaian Hasil Proses Belajar. Bandung: Remaja Rosdakarya.

Mariya. (2019). Keefektifan Model Problem Based Learning Untuk Meningkatkan Hasil Belajar IPA. 3(November), 1216-1225.

Ningsih, Y. (2019). Pengaruh Model Pembelajaran Guide Teaching Berbantuan Video terhadap hasil belajar siswa pada mata pelajaran IPS di SMPN 1 Gunung Talang . http://repository.unp.ac.id/id/eprint/26444

Nopia, R., \& Sujana, A. (2016). Pengaruh Model Problem Based Learning Terhadap Keterampilan Berpikir Kritis Siswa Sekolah Dasar Pada Materi Daur Air. Jurnal Pena Ilmiah, 1(1), 641-650. https://doi.org/10.23819/pi.v1i1.2996

Nuraini, F., \& Kristin, F. (2017). Penggunaan Model Problem Based Learning (Pbl) Untuk Meningkatkan Hasil Belajar Ipa Siswa Kelas 5 Sd. E-Jurnalmitrapendidikan, 1(4), 369-379. https://doi.org/10.1080/10889860091114220

Priyatno, D. (2016). Belajar Alat Analisis Data Dan Cara Pengelolahannya Dengan SPSS. GAVA MEDIA:Yogyakarta.

Rahmadani, N., \& Anugraheni, I. (2017). Peningkatan Aktivitas Belajar Matematika Melalui Pendekatan Problem Based Learning Bagi Siswa Kelas 4 Sd. Scholaria: Jurnal Pendidikan Dan Kebudayaan, 7(3), 241. https://doi.org/10.24246/j.scholaria.2017.v7.i3.p241-250

Sapriya. (2009). Pendidikan IPS. Bandung: Rosda Karya.

Savage, V.T. \& Armstrong, D. . (1996). Effective Teaching in Elementary Social Studies. London: PrenticeHall.

Sumantri, N. (2001). Pembaharuan Pendidikan IPS. Bandung : Rosda Karya.

Sumitro, A. D. (2017). Penerapan Model Problem Based Learning Meningkatkan Motivasi dan Hasil Belajar IPS. Jurnal Pendidikan 2 (9): 1188-1195.

Agustin, V. N. (2013). Peningkatan Aktivitas dan Hasil Belajar Siswa Melalui Model Problem Based Learning (PBL). Journal of Elementary Education, Hlm. 37-43.

Syafriana, D. (2017). Penerapan Model Problem Based Learning (Pbl) Dalam Pendekatan Saintifik Untuk Meningkatkan Hasil Belajar Ipa Kelas V Sdn 63 Surabayo. Jurnal Inovasi Pendidikan Dan Pembelajaran Sekolah Dasar, 1(1), 30-43. https://doi.org/10.24036/jippsd.v1i1.7932

Varia Zuliyaningsih, E., \& Dkk. (2018). Penerapan Model Pembelajaran Problem Based Learning (PBL) untuk Peningkatan Hasil Belajar IPA Kelas V Semester II SD Negeri Boto 02 Tahun Pelajaran 2017/2018. Journal of Teaching in Elemantary, 2(1), 47-58.

Widodo, \& Widayanti, L. (2013). Peningkatan Aktivitas Belajar dan Hasil Belajar Siswa dengan Metode Problem Based Learning pada Siswa Kelas VIIA MTs Negeri Donomulyo Kulon Progo Tahun Pelajaran 2012/2013. Jurnal Fisika Indonesia, 17(49), 32-35. https://doi.org/10.22146/jfi.24410

Wulandari, B., \& Surjono, H. D. (2013). Pengaruh problem-based learning terhadap hasil belajar ditinjau dari motivasi belajar PLC di SMK. Jurnal Pendidikan Vokasi, 3(2), 178-191. https://doi.org/10.21831/jpv.v3i2.1600 